\title{
Communication: A Challenge to the Nigerian Church
}

\author{
Chika Asogwa, PhD \\ Department of Mass Communication, Kogi State University, Nigeria \\ Tel: 234-81-3004-7065Ｅ-mail: euchika@yahoo.com \\ Damian Amana \\ Department of Mass Communication, Kogi State University, Nigeria \\ Tel: 234-81-3217-6953Ｅ-mail: fr.damian@yahoo.com
}

Received: November 25, $2011 \quad$ Accepted: December 26, $2011 \quad$ Published: January 1, 2012

doi:10.5539/ach.v4n1p90

URL: http://dx.doi.org/10.5539/ach.v4n1p90

\begin{abstract}
This paper took off recognizing the zeal of the African Church specifically the Nigerian Church. The relationship between communication and the community was discussed in this paper, good communication is very essential for the growth of every human community and where this is lacking there will be a problem as in the Nigerian Church. In discussing the communicative nature of the ecclesial community, it clearly said that the church is born out of the communication of the "Word" of the father that took flesh in the world (incarnation). This paper further explored the basic communication problems of the Nigerian Church and also offered some recommendations. The Catholic Church in Nigeria needs to "purge itself of non-communicational practices and implant within its fabric, the christo-centric model of a participatory communication".
\end{abstract}

Keywords: Communication, Nigerian church, Community, Participation, Christo-centric model

\section{Introduction}

\subsection{Situational overview}

'The toad' says an African proverb 'does not scamper frenetically under the scourging midday sun for nothing: it is either pursuing something or something is after it. When in spite of the USA's declaration of Nigeria as a precarious and pernicious zone for its citizens, the highly esteemed American syndicate, National Catholic Reporter's journalist, John Allen came to Nigeria; informed tongues could not help asking why? 'I'm in Nigeria this week", he wrote "because I'm convinced that the $21^{\text {st }}$ century is likely to be an 'African century' in Catholicism, and I want to find out what makes one of the powerhouse churches of the continent tick."(Allen, 2007) He averred at the close of his journalistic reportage that "Nigeria is destined to be a key point of reference in the Church of the future. For that reason alone, it is worth keeping an eye on."(Allen, 2007) Not only John Allen but manifold and diverse scholars are acknowledging and attesting to the potency and pivotal position of the Catholic Church in Nigeria and Africa as a whole within the wider scheme of the Church's presence and mission in the world.

Tracing the historic-statistical "center of gravity" of Christianity from the apostolic age to the present day, Dr. Todd Johnson and Mrs. Sun Young forecasted that "by the dawn of the $22^{\text {nd }}$ century, the geographical heart of the Christian churches will be located in Nigeria (Kobia, 2005). Beloved Pope John Paul II who himself was familiar with the African Church from his visits, during his pontificate called this flourishing of the African church "the glorious splendour of the African church" (Ecclesia in Africa, 34).

The veracity of this positive evaluation of the Catholic Church in Africa in general and Nigeria in particular is validated by a couple of measurable indicators. First on the list is the demographic explosion. Allen rightly noted: 
"In the 20th century, Africa went from a Catholic population of 1.9 million in 1900 to 130 million in 2000 , a staggering growth rate of 6,708 percent. Half of all adult baptisms in the world, the surest sign of missionary expansion are in Africa. Inexorably, pastoral and intellectual energy in the church will follow population, and this means that African leaders are destined to play an increasingly important role. Nigeria will have 47 million Catholics by 2050, and has the human capital and ecclesiastical infrastructure to become an African 'voice' in the global Church" (Allen, 2007).

Ihejirika noted from his ethnographic research in Nigeria that between 1981 to the year 2000 the Catholic Church in Nigeria made a 63.9\% increment in population (Iherijika, 2004:11). While for Terry Leonard, from the ascendancy of Pope John Paul II to the papacy in 1978 till date, "the number or Catholics in Africa has increased 150 percent" (Leonard, 2005).

The flourishing of the African church is not only with regards to population, but even liturgy in Africa is a joyous celebration. John Allen further added "Seminaries here are full, and vocations to the religious life are booming, Parishes are very strong. Catholic spirituality here is very devotional, with lots of pious leagues and societies (Allen, 2005). This Church is truly the hope of the future of the Church (Onyalla, 2005:160).

Despite the pomp and vibrancy of the Nigerian Church, there are signs symptomatic of a gnawing and virulent malady, vitiating the validity and questioning the authenticity of the Catholic faith on the Nigerian soil. The outflow of Catholics, especially Catholic youth to the Pentecostal/ evangelical churches is simply staggering. In the Lure of the Pentecostals, Amana declares that up to half of the members of the new religious movements in Nigeria were one time Catholics or children of Catholic parents (2001:1-5). "Conversion to these churches has been on a steady increase, with membership rising up to 20 million within a thirty-year period. There has also been considerable impact on the Nigerian media landscape (Ihejirika, 2005). According to Polgreen and Rohter "fire-breathing Pentecostalism has taken Africa by storm, drawing millions with its energetic, all-night-revival style of worship and its promises of both spiritual and material riches to its faithful flock: Nigeria not excluded" (Polgreen and Rohter, 2005). From the fold of a Catholic family that apparently manifest a great vigour and vitality of faith, this outflow raises a question mark.

In this same country of blooming Catholicism and vibrant Christian communities, the crime rate is ever on the increase, winning for the nation the most corrupt country in the world in the year 1999 and there is never a crime in the country without beautiful Christian's names dominating the nefarious list of perpetrators. "Every where there is evidence of a disquieting cleavage between visible marks of the faith and moral commitment to gospel (Asambe, 2005:204).

In this same vibrant Church of Nigeria, many are Catholics in the body and traditionalist in the soul and when the 'going gets tough', many revert to their ancestral shrines for a salve. It is no wonder that Onyalla commented "the lives of many Christians in Africa are yet to be culturally and biblically integrated" (Onyalla, 2005:268). Nwaigbo added "divisions in the church of God and the body of Christ due to tribalism are scandalous to the witness of the gospel" (Nwaigbo, 2005:142).

This polarity and paradox between the apparent high level of faith in the Nigerian Church and the high flood of obvious anti-Christian attitudes and actions speaks volume-a yawning Lacuna. In the 2005 Journal of African Ecclesiastical Review, Jude Asambe makes a good summary of the situation of the Nigeria Church. In his words:

The evangelization type in Africa has produced "nominal Christians who lacked in deep faith." "Granted, there is notable development in structures such as of education, health, social sector, notwithstanding the opening of new church stations; increase in religious and priestly vocations and a significant impact of the church on the society. In spite of this progress, .... good number of the professed Catholic laity and clergy still engage in acts that are not only prejudicial to the faith but are out rightly questionable" (Asambe, 2005:203).

In the light of the foregoing overview, the paradox of the apparent virtues of the Nigerian Church cohabiting comfortably with the inherent vices in the same church is the concern of this book. It is the assumption of this book that every community is built of the bricks of communication and every real communio is an offshoot of a proper communication. The Church therefore like every human community is glued together as family with the gum of good communication, and where this is lacking, there will be problem as in the Nigerian Church. This book will therefore, continue with an operational definition of communication in the ambit of the community, a cursory look at a particular community: the church and its communicative nature. Thereupon, the book looks at how the Nigerian Church community is communicatively organized and its concomitant effect leading to a return to workable image of communication and its application to the Nigerian Church. 


\subsection{Explication of terms: communication}

There are diversified definitions of communication as there are persons and there is no univocally accepted definition of communication across the globe. This lack of a universally accepted definition of communication is rendered more difficult by the plain fact that the word and act of communication means different things to different people.

The word communication originated from the Latin verb "communicare". In the original language the word implies to make common, or to share. From this etymological root, it is not difficult to discover that the relationship between the word communication and community comes from the same root. On this plain, it is therefore logical to infer from its root that communication has a dynamic character.

Without delving unnecessarily into the sea of scholarly conjectures on the word "communication", we stick with the concept of communication conceived as sharing. Here communication is not only sending a message but a "social act that attracts reciprocity or participation, an art of self revelation, interdependence." This sort of communication inevitably leads to the creation of the community. It becomes a two way process where one can share meaning with others but above all a process through which one shares his or herself with the other. The Church's document on communication Communio et Progressio renders this more precise when it says "Communication is more than the expression of ideas and the indication of emotion. At its most profound level, it is the giving of self in love' (Communio et Progressio, 11). This sort of communication is community building.

\subsection{Relationship between communication and community.}

There is an undeniable relationship between communication and community. Community basically is an interacting group. And the degree of internal cohesion or external adhesion to the community is directly proportional to the quality of communication found within the community. It is no accident that communication and community have the same etymological root. Traced to their pedigree, communication and community comes from the Latin noun root 'communis': to make common. As Granfield noted, no community "can be established or continue to exist without communication." (Granfield, 1994:2) Communication and Community have a dialogic, two ways, and interactive process. The sort of communication that is community building noted Traber, demands participation of the varied members. (Traber, 1995: xiii)

\subsection{Communicative nature of the ecclesial community}

In the attempt to describe and capture what the Church is, many different images and ideas have been employed: Mystical body of Christ, the priestly people, the new Israel, etc. However "suffice to say that no matter what model or image is chosen to describe the Church, strong element of communication pervade and perfuse them all'(Amana, 2007:23). As Avery Dulles noted:

The basic reality on which the Church is founded is a mystery of communication: the communication of divine life to men through the incarnate life of Jesus Christ. Jesus as a divine person is God the communicator: He is the eternal word-the communicative self-expression of God the father, as incarnate word, Jesus is the one who communicates through his bodily presence in our midst by speaking, by making gestures, by his style of life, and especially by the climactic events of his death and resurrection. In the case of Jesus, it is literally true that the medium is the message. Through his incarnation, death and resurrection as media we are put in contact with the good news of his saving advent, passion and exaltation to the glory of God" (Amana, 2007:24).

The church is born out of the communication of the "Word" of the father that took flesh in the world (incarnation). The Incarnate "word" communicated his Kerygma and constituted a 'koinonia' of the twelve whom he called apostles. The twelve energised by the life-giving-spirit at the Pentecost, went forth to communicate the kerygma of the "Incarnate Word," building communities (ecclesia) of the "Word". Through an apostolic succession and a zealous bevy of missionaries, the pristine ecclesia has continued to spread "Word" even unto the terrain of Nigeria.

The communicative nature of the ecclesial community implicitly demands that the communication within the corpus of the church must be participatory in nature: since all the baptized are children of one father and members of one body: A participatory communication which facilitates the expression of people's needs and priorities through effective communication process is inevitable. A participatory communication within the body of Christ demands that the believer, having been incorporated into the body of Christ ought to participate according to the grace given him, in the planning, implementation, evaluation, of the communication that builds and sustains the body of Christ. The question we might dare to ask therefore, is how participatory is the Church in Nigeria? How involved are members in the pastoral affair? Before evaluating the Nigerian Church in the light 
of a participatory community building communication, it is fitting that we be informed about the Nigerian Church.

\subsection{A Purview of the church in Nigeria}

\subsubsection{Brief history of the church in Nigeria}

According to the history of Catholicism composed by the highest ecclesial body in Nigeria: the Catholic Bishop's conference, the attempt at communicating the "Eternal Word" to the world of Nigeria could be divided into two phases.

For the first phase, the footsteps of the missionaries bearing the "Eternal Word" graced the soil of Nigeria in the $15^{\text {th }}$ and $18^{\text {th }}$ century. This first wave of missionary campaign was championed by Capuchins and Augustinians from Portugal, Spain and Italy. Imagining the pattern of indirect state relations of the time, these missionaries sought first of all to convert kings and palaces. To the credit of this missionary endeavor, Christianity flourished briefly in Benin and Warri in Nigeria (CBCN, 2007). A 1644 document has it that:

"In the city of Warri there is a church with an altar, a crucifix, statues of Mary and the Apostles, and two candlesticks alongside. The Black people come into this church with the rosary constantly in their hands, just as proper Portuguese do. They recite it together with other popish prayers. Outwardly they show themselves very religious. They also know how to read and write and are eager for Portuguese books, pens, ink and paper" (CBCN, 2007).

Because this missionary endeavour was elitist in nature and did not penetrate the grass roots, it died with the collapse of the Itshekiri Empire.

The second wave of the missionary venture was pioneered by freed slaves and Protestants. Names like Henry Townsend and Michael Ajayi Crowther are forever indelible on the Christian history of Nigeria. For the Catholic fold, the SMA fathers championed the new course of evangelization. By 1860 one Padre Antonio already had missions going on at Lagos and later by 1868, the SMA led by Francesco Borghero laid a more solid foundation for the modern day Nigerian church (CBCN, 2007).

The seeds of the Word these missionaries planted have really borne fruit and today, the Nigerian Catholic Church can boast of 49 dioceses and 9 provinces (CBCN, 2007).

\section{Communicative Evaluation of the Nigerian Church}

From our operational explication of communication and the delineation of the interaction between communication and community, we came to the conclusion that a communication that enhances the unity of the community ought to have a participatory nature: wherein people are enriched through a reciprocal open exchange of meaning and the furtherance of common significations in the society. The question this paper seeks to address at this point therefore is: How well is the communication in the Nigerian Catholic Church participatory?

It is precisely on the count of a participatory communication that the Catholic Church in Nigeria seems to really lack a solid foundation. It is no wonder therefore, that among the five themes that preoccupied discussion during the First National Pastoral Congress of the Catholic Church In Nigeria held between November $11^{\text {th }}$ to $15^{\text {th }}$ 2005, four of the burning issues bore directly on communication: Proclamation, inculturation, dialogue, and social communications.(Onayikan, No. 3), seeking to better the communication in the Nigerian Church. The lack of a participatory communication in the Nigerian Church shows itself in a number of ways.

\subsection{Liturgical imposition}

One of the overt arenas where the communication in the Nigerian church shows sign of malady was in the initial take off of the church. As White noted,

The missionaries method was more of an imposition, The dominant communication image in this thought is that of "transport" of Information, pouring spiritual values into a cultural void or using persuasive rhetoric to rouse passive audiences (White, R., 1990)

The Missionaries though aflame with the love to spread the gospel, apart from the use of the local languages, did not reckon the rich resource and potency of religion that was already pervasive in the land. Most of the missionary importation of the Catholic faith and its presentation did not resonate with the spiritual hunger or quest of the people. A diplomat interviewed by John Allen noted that: "it's impossible to understand any kind of Nigerian... Catholicism without recognizing the powerful hold of African traditional religion on the popular mind" (Allen, 2005). Because the missionaries did not recognize the impetus of the Nigerian's religious 
weltanschauung, they could not really implant the faith, rather Christianity became titular religion while the people adhered to the tenets of their religious world view and this has not changed much. Catholicism became an externally imposed religion either in world view and liturgy.

\subsection{Syncreticism}

Consequent upon an evangelization that did not penetrate the heart of the African, there is at times the manifestation of a sort of syncretism, where the individual chooses the church for it social benefit while holding the tenets of his traditional religion in the heart. For some young member of the Catholic Church who did not grow up under the traditional religion, an inability of Catholicism to really convert the core of their heart has led to a divided fellowship, where the faith has no bearing on the other aspects of their life.

\subsection{Early method of evangelization}

The method of the primary evangelization was equally faulty, while the missionaries came with their question and answer penny catechism, religion for the Nigerian as for the "notoriously religious African" was not a matter of the head but an issue of the heart and whole life. Catholic Religious evangelization and education for a lot of Nigerians was not just a call to virtuous life of faith but an invitation to new kind of wealth and well being. The diatribe between the French Holy Ghost and the Augustinians whether to evangelize through building schools or through building churches was an open secret (CBCN, 2007). The Missionaries began mostly through what they had to give in terms of infrastructures: schools, hospitals, wells etc. The same effect is very common among some African Christians where Christianity is perceived as a call to the better and easier life. This same search for the golden fleece is still manifested today in different forms, for example lots of fracas emerges whenever there is need to choose leaders of the various groups in the church like CWO, CMO, CYWO, CYMO etc. Some even bribe to win these posts and when they eventually loose they remain perpetually in opposition with the ruling group. Are all these struggles for the service of the word of God or for personal interests?

\subsection{Materialism}

The Nigerian Church is becoming too materialistic compared to the secular world. This infringes on its ability to communicate the gospel to the people. Church should be an example in moderate and simple use of material wealth. Today, some poor people shy away from the Church/Church activities simply because they have nothing to offer. There is much emphasis on the rich members with little or no recognition of the poor, thereby gradually turning the Church to be a competitive zone where people show off their wealth and gorgeous dresses. The modern Nigerian clergy and laity have a lesson to learn from the Church of the apostolic age. To dedicate themselves to the spiritual need in the community, the apostles delegated the sharing of bread to the deacons, "This freed the apostles from such concerns that would keep them from the service to the Word. Today's apostolic descendents, on the contrary, seem to be busier with finance and administration than with the service of the Word. Much of the communication failures occur due to lack of transparency in the day-to-day dealings whether financial or otherwise. This is because truth is the foundation of all relationships and communication has to do with building up relationships" (Srampickal and Joseph, 2003, 67).

\subsection{Clericalism and Para clericalism}

One forum where the lack of a participative communication is obvious in the Nigerian Church is the overt clericalism. Clericalism is the 'application of the opinion of ordained clergy in matters of either the Church or broader political and socio-cultural import.' Clericalism consists basically in the 'identification of church with the clergy:' wherein the laity has little or no say in the governing of the church affairs. Clericalism presupposes a clergy who knows all and therefore the laity must be fed on all issues from the supposed wealth of the priest's knowledge. Under such a hierarchical, clerical and an institutional arrangement of the church, the people of God shy away from their participative function in the building up of the kingdom of God.

Srampickal and Joseph has highlighted the danger of clericalism to accountability. Under clericalism "It is hard to demand discipline and accountability from Church personnel authority. As a result, non-professionalism and mediocrity easily sweep" (Srampickal and Joseph, 2003:67) Commenting further Srampickal and Joseph noted that; "too much of clericalism is a real hindrance to communication in the community" (Srampickal and Joseph, 2003:67).

Even though that D.D. Dodo, the two time National Chairman of the Nigerian laity has highlighted the impact of clericalism to such an extent that a clergy class that has enjoyed absolute authority is terrified at the rise of the laity in leadership. Referring to the clergy, he wrote, "Some of them are not happy as they see the emergence of Laity Councils as a force that threatens their authority instead of seeing them as desirable co-workers in the Lord's vineyard who have come to play their assigned role and to supplement and complement the work of 
clergy" (Dodo, 1986, 37). This book opines that clericalism in the Nigerian church is not often manufactured by the clergy as Dodo said, but it is rather often manufactured by the laity themselves.

A good number of the laity shies away from their responsibilities in the Church; these members feel that it is the duty of the clergy to run all the Church's affairs. The laity has this mentality that the clergy knows it all and so they refer every issue to the priest expecting that whatever he says is perfect. Often the clergy is struggling to live up to these expectations of all-round excellence. A new form of clericalism emerging in the Church today is that spurred by some members of the laity who occupy specific posts. In many parishes people are more afraid of the Catechists or CWO President's than the clergy. These catechists or lay members see their statues close to that of the clergy and they "think that they are a priviledged lot and impose heavy burdens on their brothers and sisters, while they adopt different standards for themselves" (Srampickal and Joseph, 2003:67).

\subsection{Divisions}

An overt symptom revealing the lack of a communicatively united church in Nigeria is the manifold manifestations of disunity. Most projects that entail joint effort in the Nigerian church either do not take off or do not progress very well. The divisions in the Nigerian Church are an issue that call for a proper participatory communication. As Srampickal and Joseph noted.

When we are divided within, we cannot be the leaven of unity and peace in our country. Jesus expressed this conviction very forcefully and symbolically when he said, "A house divided within cannot stand" It is sad to see that often insignificant aspects of religion and rituals, take our precedence over "the weightier matters of the law" and we easily forget that in love, all the law and the prophets are fulfilled. This may be the greatest witness of Christian communication today (Srampickal and Joseph, 2003:68).

\subsection{Ethnocentrism and tribalism}

Coupled with the lack of unity is the presence of ethno-centricism and Tribalism in the Nigerian church. These two terms used in this particular parlance denote the over consciousness of the superiority of one's ethnic group and tribe and the subsequent relational modality based on affinity to the ethnic group or tribe.

It is a known fact that the Nigerian Church is still battling with tribal bias. Tribalism is manifested in the church through imbalance of power, privileges, profits, creating an environment where some are there to worship others. It can be manifested in discrimination.

The practice of ethnicism in the Nigerian Church contradicts "the universal imperative of the salvation of humanity in Africa" (Nwaigbo 2005:152). For a church that has four elements, One, Holy, Catholic and Apostolic. The presence of ethnicism is a strong indication of poor communication in the body.

\subsection{Improper use of the media}

One greatest communicational hindrance plaguing the Nigerian Church is the improper use of the media. More often than not the act of communication is identified with mass media. Such a reason seems to underline the too much emphasis laid in the imprudent strife for the provision of mass media in the different levels of the church. The whole of no 8 in the report from the first National Pastoral Congress has such a "technologised" mentality. It is worth noting that if the Church lack social communicative abilities, the purchase of the best of equipment will not make us better communicators just as the provision of a computer would not make a monkey a Bill Gate. The poor frequency to most diocesan Newspapers buttresses this fact. As the enlightened ex Prelate of Milan once noted that, " the challenge for Church communication, then, does not start with the media despite their power in the contemporary world, rather, it starts with seeing ourselves-members of the Church as communicators " (Paul Soukup, in Cardinal Martini's Pastoral letters, 1994).

In instances where the media are available, because of the Church's rigidity of form, the Church is not able to communicate in the language of the precise medium, thereby making its use futile and unproductive. The Church must really train its own experts in the field and cease the wonderful opportunity the mass media offers.

These aforementioned communication challenges reveal one basic fact, that there is a very strong practice of communication in the Nigerian Church. However, this strong communication lacks the ability to produce a unified and an integrated Christianity. It lacks a participatory character.

\section{Towards A Participatory Model of Communication in the Nigerian Church}

Having thus far analyzed the problem of communication within the fabric of the Nigerian context, this work will return to the words of the bible in search for a communication pattern and paradigm that would help to correct the malady. 


\subsection{Theological foundation of a participatory communication}

3.1.1 Trinitarian communion.

The Trinitarian doctrine holds that there are three persons equal in majesty in the one God: God the Father, God the Son and God the Holy Spirit. The Tri-unity in one God exemplifies for the Church the call to a communion and communication of equality and love. The Trinitarian paradym presents before the church an image of a participatory model of communication, of leadership, of service, that would bring the different aspects of the church into one common course.

\subsection{Pastoral Implications for the Nigerian church}

The Catholic Church in Nigeria is a promisingly potent Church. She however, cannot ignore the lessons from the archive of history. The now depleted and near empty pews of the churches in Rome, France, Ireland, England, Canada and Spain were one time flowery beds of a fecund and flourishing church. The reasons for the spiritual aridity on these lands are not too farfetched. Fledgling weeds were not nipped in the bud; they took roots and siphoned the strength of the productive stems of the church. The Church in Nigeria ought to really begin to extract from within its ranks any bit of a poor communication and in its place plant seeds of a participative communication.

This means giving each person an opportunity to participate within the activities of a Church. "Participation" according to Asogwa "empowers the members. The leader has a great role to play in encouraging participation on the part of members. This can be done in many ways like delegating certain functions to others and allowing others the use of their initiative in the execution of the delegated function while installing feedback as a means to evaluating the function in the light of community goals" (Asogwa, 2007: 96).

E. Schillebeeckx spelt out the rights of the laity to be recognised if a participatory church is to function effectively:

1. The right and freedom to hear the word of God and to participate in the sacramental and liturgical life of the Church;

2. The right and freedom to exercise the apostolate and share in the mission of the Church

3. The right and freedom to speak and be heard and to receive objective information regarding the pastoral needs and affairs of Church;

4. The right to education, to freedom of inquiry and to freedom of expression in the sacred sciences;

5. The right to free assembly and association in the Church;

6. And such inviolable and universal rights of the human person as the right to the protection of one's reputation, to the respect due to one's person, to activity in accord with the upright norm of one's conscience, to protection of privacy" (Schillebeeckx in Anusionwu, 1994:75).

\subsection{Recommendations for a participatory communication}

\subsubsection{All inclusive communication}

The church should seek and promote a communication that recognizes the potential of each of its members and listen to the needs of each one in the bid to pastoral relevancy.

\subsubsection{Pastoral collaboration}

Pastoral collaboration is an inevitable seed if the church is to be more productive. However, collaboration calls for a democratization of the governing of the structures of the church in Nigeria.

Collaboration likewise extends to non Catholics and non Christians: on this level collaboration becomes dialogue. Dialogue from the Greek word "dialogos", implies the sense of "moving through" and "shared meaning." The church called to be the sign of divine love, divine fatherhood and common brotherhood of all mankind should promote healthy image of itself and work for mutual respect for every religion in Nigerian, given the multi-ethnic, multicultural nature of our nation. According to the African synod, "Openness to dialogue is the Christian's attitude inside the community as well as with other believers and with men and women of good will. Dialogue is to be practised first of all within the family of the Church at all levels" (Ecclesia in Africa, 65).

\subsubsection{Catechesis}

Catechists should aim not in a cramming of the doctrine but conviction of faith which is the basic foundation for an authenticity of testimony. As Srampickal noted, "Being in communication challenges us to become the Good news and not just merely those who profess it” (Srampickal andJoseph, 2003, 91). 


\subsubsection{Pastoral training}

Integrity of Christian life and testimony should be taken into consideration in the preparation of pastoral personnel and not just academic excellence. "The priest by word and example must call attention to higher values. Man does not live by bread alone. The priest must identify with the poor, so as to be able to bring them the uplifting Gospel of Christ" (John Paul II, sermon in Nigeria 1982).

Ministers should be thoroughly bred in the art of empathic listening. "This listener should desire genuinely to understand what others are trying to communicate" (Mayer, 2000: 127). Listening here is by no means relegated to listening to persons, listening likewise includes the ability to read the feedback: to know what we are doing communicatively. According to Meissner "feedback is essential to the attainment of group goals, if it is inadequate or ignored, the result will be ineffective operation, failure and possibly disintegration of the group." (Meissner, 1965:35).

\subsubsection{Use of the media}

Pastoral personnel should be professionally trained first of all in the art of social communications, then, in the language of the media while not undermining the important place of the traditional forms of social communications. "These forms include songs and music, mimes and the theatre, proverbs and fables. As vehicles of the wisdom and soul of the people, they are a precious source of material and of inspiration for the modern media" (Ecclesia in Africa, 123).

\subsubsection{Promotion of a common image: family of God on mission.}

Most often in life, people pattern their lives according to predominant symbols in their environment. The Church in Nigeria likewise must emphasis and orchestrate its pastoral ministry around the image chosen for the African church at the African synod: "Family of God on mission."

The promotion of the common image however goes far deeper than just a mere nomination. It implies that seminary, parish and administrative structures should be modeled upon the image of the family: the chosen image of the African church. For this same reason, the bigger parishes and faith communities should be organized into small basic Christian communities to foster unity.

\subsubsection{Inculturation}

If the Catholic faith is to be thoroughly implanted on the soil of Africa, then inculturation is more than a necessity. The Special Assembly of the African synod, considered inculturation a major priority for the African church.(Ecclesia in Africa, 78) According to John Paul II "the synthesis between culture and faith is not only a demand of culture but also of faith." Because "a faith that does not become culture is not fully accepted, not entirely thought out, not faithfully lived"(Ecclesia in Africa, 78).

Inculturation implies, "the intimate trans-formation of authentic cultural values through their integration in Christianity and the insertion of Christianity in the various human cultures."(RM, 52) Inculturation is not limited to just liturgy, but include the whole gamut of theology, customs, structures without tempering with the dogma of faith. According to the deliberations of the African synod and "The challenge of inculturation in Africa consists in ensuring that the followers of Christ will ever more fully assimilate the Gospel message, while remaining faithful to all authentic African values. (Ecclesia in Africa, 78).

\section{Conclusion}

This article took off recognizing and admiring the zeal and zest of the African church in general and the Nigerian Catholic Church in particular. However, unlike most of the early authors cited, this book holds a hypothetical vista with regards to the potency and place of the Nigerian Catholic Church within the overall mission of the Catholic Church upon the earth. The book holds a hypothetical stance because the promising potency of the Nigerian church is debilitated by symptoms that like an infinitesimal virus posses the venom to enervate the church's inner communion and outer witness. Such an argument was based on the 'present structure of parochial and sacramental administration that do not respond effectively to the deepest needs and aspirations of the faithful, hence a good number of the faithful flirt with mushrooming Christian sects in search of healing and miracles,' African Traditional religions and all sorts of corrupt practices in the nation (Asambe 2005:204).

It is the conviction therefore, of this article, that if the Nigerian church is to really stand as a giant that it is and play a decisive role in the church of tomorrow, the church has first of all to purge itself of non-communicational practices and implant within its fabric, the christo-centric model of a participatory communication, relying all the way on the grace of God. For, in the Christian communicational encounter, "It is God himself who meets us: God is communication, able to heal our failed communications and to fill us again with the grace of a healthy 
and constructive give and take in relationships" (Carlo Maria Martini, 1994:27). God self-communication, therefore should challenge us to work towards One, Holy Catholic and Apostolic community of God where participatory communication would be the order of the day.

\section{References}

Allen, J. (2007). Two parallels for understanding the 'powerhouse' church Nigeria. [Online] Available: http://ncrcafe.org/node/967

Amana, D. (2001). The lure of the Pentecostals. Jos: Bachelors thesis. St. Augustine Major Seminary, Jos.

Anusionwu, V. (1994). The role of the laity in missionary activity of the church in Igboland of Nigeria: a historical and pastoral approach. Romae: Pontifica Universitas Urbaniana.

Asambe, J. (2005). Evangelization, challenges and prospects for the Nigeria church. African Ecclesiastical Review.

Asogwa, C. (2007). The Relevance of communication in conflict resolution with particular reference to community living in the religious life. Rome: Licentiate thesis, Gregorian University, Rome.

CBCN: Catholic Bishop's Conference of Nigeria. The Catholic Church in Nigeria a brief history. [Online] Available: http://www.cben.org/aspscripts/page1.ASP

Ecclesia in Africa, post-Synodal Apostolic Exhortation. Rome: Libreria Editrice Vaticana.

Eilers, F. J. (1997). Communio et Progressio. In Church and Social Communication. Manila: Logos (Divine word) publication.

Granfield, P. (1994). The Church and Communication. Kansas City: Sheed \& Ward.

Idowu, W. (2004). Ethnicity, ethnicism and citizenship: a philosophical reflection on the African experience. Jos social science magazine, 8(1): 45-58.

Iherijika, W. (2006). From Catholicism to Pentecostalism, role of Nigerian televangelists in religious conversion. Port Harcourt: Port Harcourt Press.

John, P. II. (1991). Encyclical Letter, Redemptoris Missio. Mission of the Redeemer (7 December, 1990), AAS 83, pp. 249-340.

Kobia, S. (2005). Challenges Facing the Ecumenical Movement in the 21 $1^{\text {st }}$ Century. [Online] Available: $\mathrm{http} / / /$ www.oikoumene.org/en/resources/documents/wcc-programmes/ecumenical-movement-in-the-21st-century /foundational-texts/22-10-05-challenges-facing-the-ecumenical-movement-in-the-21st-century.html

Leonard, T. (2005). African catholic church growing rapidly. [Online] Available: http://www.freerepublic.com/focus/f-news/1384382/posts

Martin, R. (1995). The Catholic Church at the end of an age: what is the spirit saying? San Francisco: Ignatius Press.

Martini, C. (1994). Communicating Christ to the world. Kansas: Sheed and ward.

Mayer, B. (2000). The dynamics of conflict resolution. U.S.A.: Jossey-Bass.

Media and fundamentalism in Nigeria. Media development 2005/2. [Online] Available: http://www.wacc.org.uk/wacc/publications/media_development/2005_2/media_and_fundamentalism_in_nigeria Meissner, W. (1965). Group Dynamics in the Religious Life. Indiana: University of Notre Dame Press.

Nwaigbo, F. (2005). Tribalism Versus Evangelization in sub-saharan Africa. African Ecclessiastical Review, 131-158.

Ojo, G. A, and Dodo, D. D. (1986). Activites of the laity at the parish level. Nigeria: Layon security and colour printers.

Onaiyekan, J. (2002). Message of the First National Pastoral Congress of the Catholic Church In Nigeria held at Ibadan, at SS. Peter \& Paul Major Seminary. NOVEMBER 11-15. [Online] Available: http://www.fides.org/eng/vita_chiesa/nigeria_22112002.html

Onyalla, D. B. O. (2005). Tribalism in Religious communities in Africa. African Ecclesiastical review.

Paulus, P. P. VI. (1967). Populorum Progressio: testo e commento dell'enciclica. Roma: Citta Nuova.

Polgreen, L. and Rohter L. (2005). Third-World church's clout rises in International Herald Tribune. [Online] Available: http://www.iht.com/articles/2005/04/04/news/outpost.php 
Soukup, P. (1994). In Communicating Christ to the world. The pastoral letters of Cardinal Martini Kansas: Sheed and ward.

Srampickal, J and Joseph, J. (2003). Babel to Babri Masjid and Beyond. Media House, Delhi.

The Word became flesh: paradigm for pastoral communication in contemporary society. Rome: License Thesis. Gregorian University, Rome.

Traber, M. (1985). Communication for all. Philip Lee(ed). Maryknoll, New York: Orbis books.

U.S Department of State, 2006. Travel Warning. [Online] Available: http://www.travel.state.gov/travel/cis_pa_tw/tw/tw_928.html

White, R. (1990). The communication process of Inculturation: An “Inside view". Communication Socialis year book, vol.IX, 172-192. 